\title{
THE EFFECTIVENESS OF ACROSTICS METHOD IN IMPROVING STUDENTS VOCABULARY ACHIEVEMENT AT SEVENTH GRADE STUDENTS OF MTS AL- FURQON PRABUMULIH
}

\author{
Henny Yulia ${ }^{1}$, Mila Arizah ${ }^{2}$, Ridwan $^{3}$
}

\begin{abstract}
ABSTRAK
Masalah penelitian ini berkaitan dengan penggunaan metode akrostik dalam mengajar kosakata. Tujuan dari penelitian ini adalah untuk mengetahui apakah metode akrostik efektif digunakan dalam pengajaran kosakata kepada siswa kelas tujuh Madrasah Tsanawiyah Al-Furqon Prabumulih. Dalam penelitian ini, metode pra-eksperimen digunakan. Populasi penelitian ini adalah semua siswa kelas tujuh di Madrasah Tsanawiyah Al-Furqon Prabumulih. Jumlah total populasi penelitian ini adalah 121 siswa dan sampel adalah 31 siswa untuk kelompok eksperimen yang diambil dengan menggunakan cluster sampling. Data dikumpulkan dengan menggunakan tes. Tes ini terdiri dari 26 item dalam bentuk pilihan ganda. Data yang diperoleh melalui tes dan analisis dilakukan dengan menggunakan t-test independen di SPSS 21. Hasilnya ditemukan skor rata-rata pretest adalah 34,23 dan skor rata-rata post-test adalah 74,56. Dan berdasarkan perhitungan t-test, nilai Sig. (2-tailed $)=0,000$ kurang dari tingkat signifikansi $(a=0,05)$. Nilai $t$ diperoleh $=11,549$ lebih dari ttabel $=1,693$ dengan $\mathrm{df}=32$, dan nilai og Sig. $(2-$ tailed $)$ adalah 0,000. Itu kurang dari tingkat signifikansi $(\mathrm{a}=0,05)$. Berdasarkan hasil ot t-test yang telah diberikan, dapat disimpulkan bahwa efektif mengajar kosa kata dengan menggunakan metode acrostics kepada siswa kelas tujuh Madrasah Tsanawiyah Al Furqon Prabumulih.
\end{abstract}

\section{Key Words: Metode Acrostics, Prestasi dalam kosakata, Keefektifan}

\section{INTRODUCTION}

In the daily newspaper tribunnews.com March 25, 2017 edition. Steve Crooks, Director of Education \& Development Research at EF English First Global, announces the results of a global "English Proficiency Index" survey that shows that indonesia is in the rank of 32 nd from 72 countries in English. These survey include parts of grammar, vocabulary, reading and listening. EF announced the results of a global survey of 'English Proficiency Index' (EF EPI) in Jakarta, with Indonesia score
52.91 , is in $32^{\text {nd }}$ position from 72 countries surveyed globally.The results of this year's survey show Singapore as an Asian country with the highest rank in terms of English proficiency, followed by Malaysia and Philippines which includes the top 15 . On the other hand, Indonesia achieved lower values than some of its neighbors in the region, including Vietnam which is in the $31^{\text {st }}$ position which is classified as 'middle level'.To improve our level to be better it takes the willingness and motivation of us to study English, so that English language 
ability in our country at least can match wih our other neighbor country.According to Juniar (2016) motivated learner are more enthusiastic, goal oriented, committed, persistent and confident in their learning.

Therefore, to increase the rank of Indonesia to better than the current ranking we must give motivation and use various ways and methods so that our English ability can be better than other countries at least from our nearest neighbor country.

Based on the writer's observation about students English ability in the seventh grade students of MTs Al Furqon Prabumulih, they had difficulties in producing sentences and understanding the meaning of the words. These problems indicate that (1) they have lack of vocabulary knowledge; (2) they often gave up trying to understand the meaning of the words; (3) they couldn't arrange the sentences correctly; (4) they are difficult to memorize the meaning of the words and remembering new vocabulary. This fact can be seen from the results of their semester test which value is below from the up grade specified. Therefore, it is necessary for the teacher to apply certain technique to solve those problems and makes the students interested to learn English and can increase their English value according to specified up grade. One of the techniques is Mnemonic.

According to Foster (2009:123) mnemonic is a way of organizing information to make it easier to remember, typically by using codes, visual imagery, or rhymes (sometimes in combination). Mnemonics technique is a way to help students remember information more effectively and easly. This technique is best used in studying vocabulary in English. Mnemonics technique can be very effective and easy to be applied.Students can master vocabulary easier and fun. These techniques used to aid the recall of new information. The implementation of Mnemonic technique help them to remember more information they have learned and also can strengthen their vocabulary mastery. There are students who prefer to find the meaning of words from the dictionary and save it in their memory. Therefore, mnemonics technique can be used to memorize difficult words, while the words which are easy to remember are not necessary to use this technique. It can motivate the students and the classroom will be more interesting.

One of Mnemonics technique is Acrostics method.According to Bakken (2017) acrostics are a sentence that is developed to help the person retrieve letters. These letters then represent something that the person needs to remember. The sentence is a (catchy) way to make the information more meaningful and easier to remember. So the researcher is interested to do a research with the title "The Effectiveness of Acrostics Method in Improving Students Vocabulary 
Achievement at Seventh Grade Students of MTs Al Furqon Prabumulih"

\section{Research Question}

The problem of this study is formulated in this question: " was it effective to use acrostics method to improve students' vocabulary achievement at the seventh grade of Mts Al Furqon Prabumulih?

\section{Research Method}

The method be used in this study was Pre-experimental menthod. Pre-experimental method is a method which only consists of one group for the treatment and no control group. It is be a group as a sample that given a pre-test, treatment and final test as a posttest. In this study, the researcher applied acrostics method. This research was designed by this diagram below:

Where:

\begin{tabular}{lll}
$\mathrm{O}_{1}$ & $\mathrm{X}$ & $\mathrm{O}_{2}$ \\
\hline
\end{tabular}

$\mathrm{O}_{1}$ : Pre-Test (a test that given before treatment).

$X$ : Treatment by using Acrostics method.

$\mathrm{O}_{2}$ : Post-Test (a test given after treatment).

In this study, the researcher stated students'vocabulary achievement as the dependent variable and teaching vocabulary by using acrostics method as the independent variable.

\section{Population and Sample of the Research}

Population in this research are the seventh grade students at MTs Al-Furqon Prabumulih. At this school there were four clasess of the seventh grade students and total number population in this research were 121 students in academic year 2018/2019.

In this study, the researcher used cluster random sampling and VII B Pi as the sample of the study that consisted of 31 students.

\section{Analyzing and Collecting the Data}

1. Individual Score

2. The Percentage of the Data

\section{RESULT AND DISCUSSION}

\section{The Result of Pre test}

In experimental class the minimum score was 19.23 and the maximum of the highest score was 65.38. The average score or mean was 34.23. Based on the score interval from 31 students in their pre-test, there were no students who got excellent score, 5 students $(16,12 \%)$ got avarage score, 3 stats et(916206)5:204) poor score, 23 students $(74,19 \%)$ got fail score. The distribution score of Pre-test was presented on the chart 1 below: 


\section{Chart I}

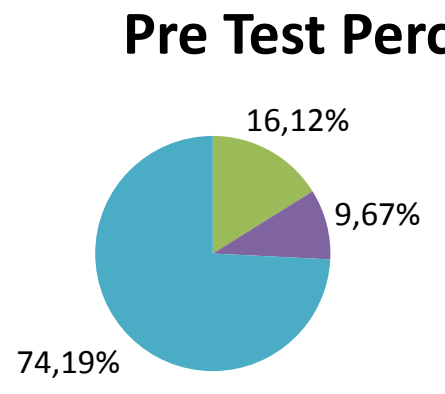

80-100 (Excelent)

- 66-79 (Good)

56-65 (Average)

46-56 (Poor)

0-45 (Fail)

The Result of Post - test

Based on the table above, In experimental class the minimum score was 65.38 and the maximum of the highest score was 84.61. The average score or mean was 74.56. Based on the score interval from 31 students in their pre-test, there were 8 students $(25.80 \%)$ got excelent score, 20 students $(64.51 \%)$ got good score, 3 students (9.67\%) got avarage score. The distribution score of Post-test was presented on the chart 2 below:

\section{Chart 2}

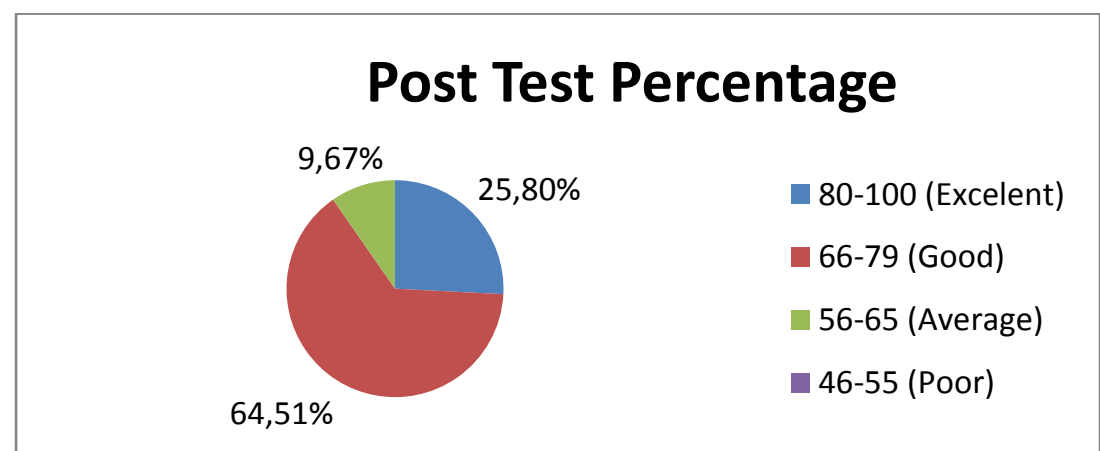

The Statistic Analysis Used Paired Sample T - Test

There are two hypotheses of this analysis step. The hypotheses were as follow:

Ha: there was a significance effective after the treatment process.

Ho: there was no significance effective after the treatment process.

If the value of $t_{\text {obtain }}>\mathrm{t}$ table, and the value of sig. (2-tiled) < significance $(0,05)$, it means that Ha was accepted.
Based on the table above, the researcher could concluded that the mean score of pre-test was 34,23 and of post-test was 74,56. Then from the table the researcher found that the value of $t$ obtain $(11,549)$ was more than value of $t$ table $(1,695)$. It was less than significance level (a $=0,05)$. It mean that alternative hypothesis (Ha) was accepted and null hypothesis (Ho) was rejected. On acrostics method was significantly effective to teach vocabulary by 
using acrostics method to the seventh grade students at Mts Al Furqon Prabumulih.

\section{FINDING AND DISCUSSION}

From the calculation in this research, the writer interpreted that it was significantly effective to use Acrostics Method in teaching vocabulary mastery, the result of pre-test was 34,23 while the result of post-test was 74,56. It showed from the score of post-test was higher than the score of pre-test. In other words, the null hypothesis was rejected, consequently the alternative hypothesis was accepted. It means that there was significantly effective to teaching vocabulary using acrostics method to the seventh grade students at Madrasah Tsanawiyah Al Furqon Prabumulih.

Based on the result of the test gave to the students, the writer concluded that, in teaching vocabulary, the teacher can use acrostics method as a new strategy to enrich the students vocabulary mastery. Acrostics method is a technique to help students get the information more meaningful and easier to remember.

Based on the explanation above, acrostics method was an alternative method in teaching vocabulary mastery.

\section{CONCLUSION}

The result it was found the mean score of pre-test was 34,23 and the mean score of post-test was 74,56 . It can be seen from the differences between the students' average score in post-test and pre-test.Based on the finding above, it could be concluded that the use of acrostics method in teaching vocabulary to the seventh grade students at Madrasah Tsanawiyah Prabumulih enable for students to get better score and motivation on learning vocabulary. It procedure strategy in improving the students' vocabulary mastery could be more effective.

\section{REFERENCES}

Bakken, J. P. 2017. Mnemonic Strategies: Helping students with intellectual and developmental disabilities remember important information. Glob J Intellect Dev Disabil. 2017; 2(3): 555587

Cohen, L., Lawrence, M., \& Keith, M. 2007. Researching method in education. ( $5^{\text {th }}$ ed.). New York: Routledge.

Foster, J. K. 2009. Memory: A very short introduction. New York: Oxford University Press.

Juniar, R. 201). The role of motivation in learning english for indonesian students. International journal of management and applied science, 2 , 65-68.

Pennington, M. 2009 How to memorize using the catch sentence (Acrostic) technique. Retrieved from $\mathrm{http} / / /$ blog.penningtonpublishing.co $\mathrm{m} /$. 